\title{
Ortaokul Öğrencilerinin Basit Makineler Ünitesi ile İlgili Anlayışlarını Ö̉çmeye Yönelik Bir Test Geliştirme Çalışmasıı
}

\section{Development of an Instrument for Measuring Secondary School Students' Understanding of Simple Machines Unit}

\author{
Hasan ÖZCAN ${ }^{2}$ İsmail ÇETINKAYA ${ }^{3}$ Selçuk ARIK ${ }^{4}$
}

\begin{tabular}{|c|c|}
\hline $\begin{array}{l}\text { Anahtar Kelimeler } \\
\text { Fen ĕ̈itimi, } \\
\text { fen bilimleri dersi, } \\
\text { basit makineler, } \\
\text { başart testi }\end{array}$ & $\begin{array}{l}\text { Özet } \\
\text { Bu araştırmada, sekizinci sınıf öğrencilerinin Fen Bilimleri dersi basit makineler } \\
\text { ünitesinin kazanımlarına yönelik akademik başarılarını ölçmek üzere bir test } \\
\text { geliştirilmesi amaçlanmıştır. Araştırmanın çalışma grubunu, 2017-2018 eğitim ve } \\
\text { ögretim yılında Aksaray il merkezinde bir devlet ortaokulunda öğrenimine devam } \\
\text { etmekte olan, basit makineler ünitesini tamamlamış } 160 \text { sekizinci sınıf öğrencisi } \\
\text { oluşturmuştur. Testin amacı dikkate alınarak alanyazın incelenmesi sonucunda } 25 \\
\text { çoktan seçmeli sorudan oluşan madde havuzu hazırlanmıştır. Testin kapsam ve } \\
\text { görünüş geçerliğini sağlamak üzere uzman görüşüne başvurulmuş ve } 20 \text { maddelik } \\
\text { taslak test oluşturulmuştur. Taslak testin pilot uygulaması } 24 \text { ögrenci ile } \\
\text { gerçekleştirilmiştir. Pilot uygulama sonrasında yapılan madde analizi ile ortalama } \\
\text { madde güçlük indeksi (pj=.57) ve ortalama madde ayırt edicilik indeksi (rjx=.50) } \\
\text { belirlenmiştir. Testin güvenirliği ise KR-21 güvenirlik katsayısı (.741) hesaplanarak } \\
\text { belirlenmiştir. Araştırmanın bulguları, "Basit Makineler Ünitesi Akademik Başarı } \\
\text { Testinin” } 18 \text { çoktan seçmeli sorudan oluşan geçerli ve güvenilir bir test olduğunu } \\
\text { göstermektedir. }\end{array}$ \\
\hline $\begin{array}{l}\frac{\text { Key Word }}{\text { Science education, }} \\
\text { science course, } \\
\text { simple machines unit, } \\
\text { achievement test }\end{array}$ & $\begin{array}{l}\text { Abstract } \\
\text { The aim of this study is to develop an achievement test consisting of multiple choice } \\
\text { questions about the simple machines' unit covered in the secondary school science } \\
\text { curriculum. The sampling of the study comprises of } 160 \text { 8th grade students who } \\
\text { completed their simple machines unit, studying in a city center school located in a } \\
\text { district of one of the metropolitan municipalities in Turkey for the } 2017-2018 \text { school } \\
\text { year. Considering the purpose of the test, a pool of items consisting of } 25 \text { multiple } \\
\text { choice questions was prepared as a result of the review of the literature. The piloting } \\
\text { of the 20-question achievement test constructed as a result of expert opinion was } \\
\text { carried out. The average item difficulty index (pj = .57) and the average item } \\
\text { discrimination index (rjx }=.50 \text { ) were determined by item analysis performed after the } \\
\text { pilot implementation. The reliability of the test as determined with reliability } \\
\text { coefficient (.741). and use of KR-21. The analyses of the data showed that the 18-item } \\
\text { achievement test is reliable and valid. }\end{array}$ \\
\hline
\end{tabular}

\begin{tabular}{ll} 
Atıf için: & Özcan, H., Çetinkaya, İ., \& Arık, S. (2021). Ortaokul öğrencilerinin basit makineler ünitesi ile \\
For Citation & ilgili anlayışlarını ölçmeye yönelik bir test geliştirme çalışması Muğla Sitkl Koçman \\
& $\begin{array}{l}\text { Universitesi Eğitim Fakültesi [MSKU Journal of Education], 8(1), 16-36. DOI: } \\
\text { 10.21666/muefd.742102 }\end{array}$ \\
\hline & Received: $24.05 .2020 \quad$ Accepted: 27.12 .2020 \\
\hline
\end{tabular}

Günümüzde bilim ve teknolojide "nitelikli insan" kavramı büyük önem kazanmıştır. Nitelikli insanlar geleceğin koşullarına uyum sağlayabilen, kendi kendine öğrenebilen ve kendi kendini değerlendirebilen (Zimmerman, 1989), hayat boyu öğrenen (Field, 2001), edindiği bilgiyi etkili bir şekilde kullanabilen,

\footnotetext{
${ }^{1}$ Bu çalışma, ikinci yazarın yüksek lisans tezinden türetilmiştir.

${ }^{2}$ Aksaray Üniversitesi, Eğitim Fakültesi, hozcan@aksaray.edu.tr ORCID: 0000-0002-4210-7733

${ }^{3}$ MEB, Kayseri.i_ck38@hotmail.com ORCID:0000-0001-9988-5467

${ }^{4}$ Tokat Gaziosmanpaşa Üniversitesi Eğitim Fakültesi, selcuk.arik@gop.edu.tr ORCID: 0000-0003-4496-8104
} 
üst düzey düşünme (Flavell, 1979), eleştirel düşünme (Ennis, 1985), yaratıcı düşünme ve öz düzenleme (Shulman, 1987) gibi becerilere sahip kişilerdir (Voogt ve Pareja Roblin, 2010; Arık, 2017). Işık'a (2003) göre "modern insan" olarak ifade edilen bu özeliklere sahip bireyler toplum temelinde geleceğin inşa edilmesi sürecinde etkin bir konuma sahiptirler (Çetinkaya, 2019; Işık, 2003). Nitelikli bireylerin yetiştirilmesinde ise iyi bir eğitim büyük önem arz etmektedir (Adıgüzel ve Sağlam, 2009; Karakaya, Arık ve Yılmaz, 2019; Özcan, Koca ve Söğüt, 2019). Başarılı bir eğitim ise eğitimin amac1 (hedef), içeriği, öğrenme-öğretme süreci ve ölçme-değerlendirme boyutları arasındaki ilişkiyi içeren öğretim programları ile mümkündür (Demirel, 2005; Küçükahmet, 2002; Yeşilyurt, 2012). Öğretim programı geliştirmenin en son basamağı olan ölçme ve değerlendirme, diğer üç boyutla bağlantılı en önemli süreçlerden bir tanesidir. Ölçme ve değerlendirme süreci, öğretim programının işlevselliğini, öğretim strateji, yöntem ve tekniklerinin verimliliğini, öğrenenlerin öğrenme sürecinde yaşadıkları güçlükleri ve başarı durumlarını belirlemede çok önemlidir (Baykul, 2015; Demirel, 2005; Grounlund, 1985; Küçükahmet, 2002). Bireylerin eğitim sürecinde veya belirli çevre koşullarında ne kadar öğrenip öğrenmediğini belirlemek üzere yapılan testler maksimum yeterlik testlerinden bir tanesi olan "başarı testleri” dir (Doğan, 2009a; Tezbaşaran, 2008). Başarı testleri öğrencilerin anlamlı öğrenmelerinin tespiti edilmesini, öğrencilerdeki değişimin gözlemlenmesi, analiz edilmesi ve değerlendirilmesi bakımından önemlidir. Bu testler ders veya kurs sonunda kazandırılması düşünülen başarının ölçülmesi amacıyla "erişi testi" olarak; ders veya kurs sürecinde kazandırılması düşünülen davranışlarının ne kadarının kazandırıldığını ölçmek amacıyla "izleme testi” olarak; ders veya kurs başlamadan öğrencinin kazandırılması düşünülen davranışlarının ne kadarına sahip olduğunu belirlemek amacıyla “hazırbulunuşluk testi” olarak uygulanabilir (Yıldırım, 1999'dan akt. Doğan, 2009a).

Tekin (1994)'ün sınıflandırmasına göre: Başarı testleri dile dayanma durumuna göre; dile dayanan testler ve dile dayanmayan testler olarak sinıflandırılabilir. Dile dayanan testler; yazılı ve sözlü sınavlar olarak sınıflandırılır. Yazılı sınavlar ise essay tipi sınavlar, kısa cevaplı testler, seçmeli testler, doğruyanlış testleri ve eşleştirmeli sorular olarak sınıflandırılabilir (Tekin, 1994'ten akt. Doğan, 2009a).

$\mathrm{Bu}$ yazılı sınavlar içinden çoktan seçmeli sınavlar; uygulama zamanının kısa olması, daha fazla soru içermesi dolayısıyla daha geçerli ve güvenilir olması, puanlamasının objektif ve kolay olması, eğitimin hemen hemen her basamağında (üçüncü sınıftan itibaren) uygulanabilir olması, çok sayıda kişiye uygulanabilmesi, istatistiksel temellere dayanması bu sayede yanıtların doğruluğu ve güçlüğünün hesaplanması gibi özellikleri bakımından çoktan seçmeli testler ulusal ve uluslararası sınavlar olmak üzere birçok sınavda kullanılmaktadır (Crocker ve Algina, 1986; Doğan, 2009b; Güler, 2013; Katz ve Slomka, 1999; Tekindal, 2017).

Özellikle ulusal düzeyde T.C. Ölçme, Seçme ve Yerleştirme Merkezi (ÖSYM), Milli Eğitim Bakanlığ1 (MEB) ve çeşitli üniversiteler tarafından yürütülen sınavlar çoktan seçmeli akademik başarı testleri aracılığıyla gerçekleştirilmektedir (Karakaya, Arık, Çimen ve Yılmaz, 2019; MEB, 2020a; ÖSYM, 2020). Uluslararası düzeyde yapılan "Uluslararası Öğrenci Değerlendirme Programı (The Programme for International Student Assessment, PISA)" (Özgürlük, Ozarkan, Arıcı ve Taş, 2016), "Uluslararası Matematik ve Fen Eğilimleri Araştırması (Trends in International Mathematics and Science Study (TIMMS))" (MEB, 2020a) vb. sınavlarda da soruların bir kısmı çoktan seçmeli sorulardan oluşmaktadır. Çoktan seçmeli akademik başarı testlerinin ulusal ve uluslararası alanda en çok uygulandığı branşlardan bir tanesi de fen bilimleri eğitimidir (MEB, 2020a; ÖSYM, 2020; Özgürlük vd., 2016; Özcan vd., 2019). 2017 Yılı Fen Bilimleri Dersi Taslak Öğretim Programı incelendiğinde, eğitim ve öğretimde değerlendirmenin; tanıma (hazırbulunuşluk), izleme ve erişi olmak üzere üç farklı şekilde değerlendirme yapıldığı belirtilmiştir (MEB, 2017). Daha önce de ifade edildiği gibi öğrenenlerin hazırbulunuşluk, izleme ve erişi bakımında değerlendirilmesi akademik başarı testleri aracılığıyla yapılabilir (Yıldırım, 1999'dan akt. Doğan, 2009a).

Ulusal alanyazın incelendiğinde fen eğitimine yönelik olarak birçok konu ve üniteyle ilgili (fen bilimleri (Aytekin, 2018), basınç (Özcan vd., 2019), basit makineler (Özkan ve Eryılmaz Muştu, 2018), hücre (Özcan, Boz ve Özkaya, 2020), vücudumu bilmecesini çözelim (Şener ve Taş, 2017), 1s1 ve sıcaklık (Ayvacı ve Durmuş, 2016), kuvvet ve hareket (Akbulut ve Çepni, 2013), çözeltiler ve fiziksel özellikleri (Tosun ve Taşkesenligil, 2011), iş ve enerji (Açıkgöz ve Karsl1, 2015), modern fizik (Demir ve Akarsu, 2014), basit elektrik devreleri (Şen ve Eryılmaz, 2011), maddenin tanecikli yapısı (Kenan ve Özmen, 2014), genetik (Çakır ve Aldemir, 2011), ışık ve ses (Şenel Çoruhlu, Er Nas ve Keleş, 2016), yer kabuğunun gizemi (Sontay ve Karamustafaoğlu, 2017) vb. başarı testi geliştirme çalışmasının yapıldığ1 
gözlemlenmektedir. Fen eğitiminde öğrenenlerin kavramsal anlayışlarını geliştirmek, başarı düzeylerini belirlemek, öğretim yöntem ve tekniklerinin etkililiğini araştırmak, kavram yanılgılarını ve yanlışlarını belirlemek açısından akademik başarı testleri büyük önem arz etmektedir. Bu bağlamda tüm konu ve ünitelere ilişkin geçerliği ve güvenirliği yapılmış akademik başarı testleri geliştirilmelidir.

Basit makineler, günlük yaşamda (makas, vida, pense, el arabası, saat vb.) sıklık öğrenen bireylerin karşısına çıkan en önemli fizik konularından bir tanesidir (MEB, 2018). Günlük hayatta sıklıkla karşımıza çıkmasına rağmen basit makineler konusu; öğrencilerin en zorlandıklarını ifade ettikleri ve kaygı duydukları (Diken, 2018), öğretmen adaylarının kavramsal anlamalarının düşük olduğu (Bilgin ve Kala, 2018), kavram öğretiminde en zorlandıkları (Güneş, Korkmaz, Çakır, Erdoğmuş ve Çakır, 2019) ve çeşitli kavram yanılgılarına sahip oldukları (Avc1, Kara ve Karaca, 2012) konulardan bir tanesidir. Ayrıca alanyazın incelendiğinde, basit makineler konusunun özellikle Fen, Teknoloji, Mühendislik ve Matematik (STEM) eğitimi (Acar, Korkmaz, Çakır, Erdoğmuş ve Çakır, 2019; Kutlu, 2019; Özlen, 2019; Sungur Gül ve Marulcu, 2014; Uğraş ve Genç, 2018), laboratuvar eğitimi (Erkol, Kışoğlu ve Gül, 2017; Telli, Yıldırım, Şensoy ve Yalçın, 2004) ve çeşitli yarı deneysel araştırmalarda yöntem ve tekniklerin etkililiğini belirlemede (Akbaş ve Almalı, 2018; Çelik, 2015; Sertkaya, 2018; Yavaş, 2019) kullanıldığı gözlemlenmiştir. Bu bağlamda basit makineler konusunda akademik başarı testleri geliştirmenin çok önemli olduğu söylenebilir. Alanyazın taraması sonucunda basit makinelere ilişkin olarak akademik başarı testlerinin geliştirildiği çalışmalara ilişkin bilgiler Tablo 1'de verilmiştir.

Tablo 1

Basit Makineler Konusuyla İlgili Başarı Testleri

\begin{tabular}{|c|c|c|c|c|}
\hline Yazarlar & $\begin{array}{l}\text { Sinıf } \\
\text { Seviyesi }\end{array}$ & $\begin{array}{l}\text { Madde } \\
\text { Sayısı }\end{array}$ & Ünite & Konu \\
\hline $\begin{array}{l}\text { Yumuşak ve Aycan } \\
\text { (2002) }\end{array}$ & 7. Sinif & 8 & - & Basit Makineler \\
\hline $\begin{array}{l}\text { Telli, Yıldırım, Şensoy } \\
\text { ve Yalçın (2004) }\end{array}$ & 7. Sinif & $\begin{array}{l}\text { Ön test: } 20 \\
\text { Son test: } 30\end{array}$ & - & Basit Makineler \\
\hline Akbulut ve Çepni (2013) & 7. Sinif & 33 & $\begin{array}{l}\text { Kuvvet ve } \\
\text { Hareket }\end{array}$ & $\begin{array}{l}\text { Basit makineler, } \\
\text { sürtünme kuvveti vb. }\end{array}$ \\
\hline Ayazgök (2013) & 8. Sinif & 28 & $\begin{array}{l}\text { Kuvvet ve } \\
\text { Hareket }\end{array}$ & Basit makineler \\
\hline Çelik (2015) & 7. Sinif & 25 & $\begin{array}{l}\text { Basit } \\
\text { makineler }\end{array}$ & - \\
\hline Almalı (2018) & 8. Sinif & 20 & $\begin{array}{l}\text { Basit } \\
\text { Makineler }\end{array}$ & - \\
\hline İdin ve Aydoğdu (2016) & 8. Sinif & 31 & $\begin{array}{l}\text { Kuvvet ve } \\
\text { Hareket }\end{array}$ & $\begin{array}{l}\text { Basit makineler, } \\
\text { sürtünme kuvveti vb. }\end{array}$ \\
\hline $\begin{array}{l}\text { Gülmez Güngörmez ve } \\
\text { Akgün (2018) }\end{array}$ & 7. Sinif & 20 & $\begin{array}{l}\text { Kuvvet ve } \\
\text { Enerji } \\
\text { Ünitesi }\end{array}$ & - \\
\hline $\begin{array}{l}\text { Özkan ve Eryilmaz } \\
\text { Muştu (2018) }\end{array}$ & 8. Sinif & 19 & $\begin{array}{l}\text { Basit } \\
\text { Makineler }\end{array}$ & - \\
\hline
\end{tabular}

Tablo 1'deki çalışmalar incelendiğinde, basit makineler ünitesine ilişkin başarı testlerinin "kuvvet ve hareket" ünitesi altında yer aldığ1 (Ayazgök, 2013; İdin ve Aydoğdu, 2016; Akbulut ve Çepni, 2013; Gülmez Güngörmez ve Akgün, 2018) ve yedinci sınıflar düzeyinde hazırlandığ belirlenmiştir. $\mathrm{Bu}$ durumun temel nedeni 2016 y1l öncesinde basit makinelerin "kuvvet ve hareket" ünitesi altında yedinci sınıflar düzeyinde bir konu olarak yer alırken; 2013 Fen Bilimleri Ders Öğretim Programında (MEB, 2013) 2016 yılı sonrasında yapılan değişiklikle birlikte basit makineler konusu sekizinci sınıf düzeyinde ayrı bir ünite olarak (Basit Makineler Ünitesi) yer almaya başlamıştır (İdin ve Aydoğdu, 2016; Özkan ve Eryılmaz Muştu, 2018). Basit makineler ünitesine sekizinci sınıf öğrencilerine yönelik geliştirilen çeşitli test çalışmaları bulunmaktadır (Almalı, 2018; Çelik, 2015; Özkan ve Eryılmaz Muştu, 2018). Çelik (2015) tez çalışmasında yedinci sınıf öğrencilerinin fen bilimlerinde film ve çizgi film kullanılarak yapılan öğretimin fen bilimleri dersine yönelik tutumları ve akademik başarılarına etkisini incelemiştir. Bu doğrultuda "Kuvvet ve Hareket" ünitesinin "Basit Makineler" konusuna yönelik fen bilimleri akademik başarı testini geliştirmiştir. 21 maddeden oluşan bu test yedinci sınıf öğrencilerine yönelik 
olmakla birlikte kuvvet konularını da içermektedir. Özkan ve Eryılmaz Muştu (2018) çalışmalarında sekizinci sınıf basit makineler ünitesine yönelik çoktan seçmeli sorulardan oluşan bir başarı testi geliştirmeyi amaçlamışlardır. Bu amaç doğrultusunda 2016-2017 eğitim-öğretim yılında verilerini topladıkları araştırmada 2013 Fen Bilimleri Ders Öğretim Programında (MEB, 2013) 2016 yılı sonrasında yapılan değişiklikle birlikte belirlenen kazanımlara uygun 19 çoktan seçmeli maddeden oluşan bir başarı testi geliştirmişlerdir. Almalı (2018) tez çalışmasında köy enstitülerinde yapılan etkinliklerin sekizinci sınıf öğrencilerinin akademik başarılarına, fene yönelik tutumlarına ve fen öğrenme yaklaşımlarına etkisini araştırmıştır. Bu amaç doğrultusunda 2016-2017 eğitim-öğretim yılında verilerini topladıkları araştırmada 2013 Fen Bilimleri Ders Öğretim Programında (MEB, 2013) 2016 yılı sonrasında yapılan değişiklikle birlikte belirlenen kazanımlara uygun 20 çoktan seçmeli maddeden oluşan bir başarı testi geliştirmişlerdir. Alanyazın incelemesi sonucunda geliştirilen basit makineler ünitesi testlerinin 2013 Fen Bilimleri Ders Öğretim Programında (MEB, 2013) 2016 y1lı sonrasında yapılan değişiklikle birlikte belirlenen kazanımlara uygun olarak hazırlandığı belirlenmiştir. Ancak 2017 Y1lı Fen Bilimleri Dersi Taslak Öğretim Programı (MEB, 2017) ve 2018 Yılı Fen Bilimleri Dersi Öğretim Programı (MEB, 2017) kazanımlarına uygun olarak hazırlanmış basit makineler ünitesi başarı testine rastlanmamıştır. Bu bağlamda bu araştırmanın alanyazındaki boşluğu dolduracağı ifade edilebilir.

$\mathrm{Bu}$ araştırmanın amacı, sekizinci sınıf öğrencilerinin basit makineler ünitesine yönelik akademik başarılarını ölçmek amacıyla çoktan seçmeli sorulardan oluşan geçerli ve güvenilir bir test geliştirilmektir.

\section{Yöntem}

\section{Araştırma Modeli}

Test geliştirme, özellikleri önceden belirlenen belirli bir yaklaşımla kestirilebilen bir test hazırlama işidir (Baykul, 2015). Bu araştırmada, sekizinci sınıf öğrencilerinin fen bilimleri dersi basit makineler ünitesinin kazanımlarına yönelik kavramsal anlamalarını ölçmek üzere çoktan seçmeli sorulardan oluşan geçerli ve güvenilir bir test geliştirme çalışması yapılmıştır.

\section{Çalışma Grubu}

$\mathrm{Bu}$ araştırmada, sekizinci sınıf basit makineler konusuna yönelik olarak öğrencilerin kavramsal anlamaların ölçülmesi amaçlanmıştır. Araştırmanın örneklemi ekonomiklik ve zaman kazancı düşünülerek (Erkuş, 2017; Yıldırım ve Şimşek, 2018) "kolaylıkla bulunabileni örnekleme yöntemine" göre belirlenmiştir. Araştırmanın evrenini, 2017-2018 eğitim ve öğretim yılında Aksaray ili merkez ilçesinde devlet ortaokulunda öğrenimine devam etmekte olan sekizinci sınıf öğrencileri oluştururken; örneklemini ise Aksaray ili merkez ilçesinde bir devlet ortaokulunda öğrenimine devam eden "basit makineler" ünitesini işlemiş olan 160 sekizinci sınıf öğrencisi oluşturmuştur.

\section{Basit Makineler Ünitesi Akademik Başarı Testi (BMÜABT) Geliştirilme Süreci}

BMÜABT'nin geliştirilmesinde Şekil 1'de verilen aşamalar izlenmiştir (Baykul, 2015; Crocker ve Algina, 1986). 


\begin{tabular}{|c|c|}
\hline Testin amacının belirlenmesi & • Testin öğrenciler yönünden kullanılış amacı \\
\hline $\begin{array}{l}\text { Testte ölçülecek özelliklerin } \\
\text { belirlenmesi }\end{array}$ & $\begin{array}{l}\text { - Konu ile ilgili alanyazın incelenmesi } \\
\text { - Belirtke tablosu }\end{array}$ \\
\hline Maddelerin yazımı & $\begin{array}{l}\text { - Kulanılacak soru türünün belirlenmesi } \\
\text { • Madde yazımında dikkat edilen hususlar }\end{array}$ \\
\hline Madde redaksiyonu & • Uzman görüşü \\
\hline $\begin{array}{l}\text { Deneme formunun } \\
\text { hazırlanması }\end{array}$ & $\begin{array}{l}\text { - Deneme grubunun seçilmesi } \\
\text { - Deneme formunun hazırlanması } \\
\text { - Uygulamanın yapılması }\end{array}$ \\
\hline Pilot test uygulaması & $\begin{array}{l}\text { - Deneme formunun uygulanması } \\
\text { - Uzman görüşü }\end{array}$ \\
\hline $\begin{array}{l}\text { Nihai testin istatistiklerinin } \\
\text { kestirilmesi: Madde } \\
\text { puanlaması, analizi ve seçimi }\end{array}$ & $\begin{array}{l}\text { - Testin İstatistiklerinin kestirilmesi } \\
\text { - Puanlama } \\
\text { - Madde analizi } \\
\text { - Madde seçimi }\end{array}$ \\
\hline
\end{tabular}

Şekil 1. Kavramsal Anlama Testinin Geliştirilme Aşamaları (Baykul, 2015; Crocker ve Algina, 1986; Haladyna, 1994, 1997)

\section{Testin Amacının Belirlenmesi}

BMÜABT, sekizinci sınıf öğrencilerinin 2018 Y11ı Fen Bilimleri Dersi Öğretim Programı'ndaki (MEB, 2018) "basit makineler" ünitesinin kazanımlarına yönelik kavramsal anlama düzeylerini belirlemek amacıyla hazırlanmıştır. 2018 Yılı Fen Bilimleri Dersi Öğretim Programı'ndaki (MEB, 2018) "basit makineler" ünitesinin kazanımları ile test maddeleri arasındaki ilişki Tablo 2'deki belirtke tablosunda verilmişstir.

Tablo 2

BMÜABT Soruların Kazanımlarına Dağılımına İlişkin Belirtke Tablosu

\begin{tabular}{|c|c|}
\hline Kazanım ve alt kazanımlar & Madde Numarası \\
\hline $\begin{array}{l}\text { F.8.5.1.1. Basit makinelerin sağladığı avantajları örnekler } \\
\text { üzerinden açıklar. }\end{array}$ & $1,3,4,6,7,9,11,13,14,15,17,18$ \\
\hline $\begin{array}{l}\text { a. Basit makinelerden, sabit makara, hareketli } \\
\text { makara, palanga, kaldıraç, eğik düzlem ve çırık } \\
\text { üzerinde durulur. }\end{array}$ & $1,3,4,5,6,7,9,11,13,14,15,17$ \\
\hline $\begin{array}{l}\text { b. Dişli çarklar, vida ve kasnakların da birer basit } \\
\text { makine olduğu görsellerle belirtilir, ayrıntıya } \\
\text { girilmez. }\end{array}$ & $3,16,18$ \\
\hline $\begin{array}{l}\text { c. } \begin{array}{l}\text { Basit makinelerde işten kazanç olmadığı } \\
\text { vurgulanır. }\end{array} \\
\end{array}$ & 1,10 \\
\hline $\begin{array}{l}\text { F.8.5.1.2. Basit makinelerden yararlanarak günlük } \\
\text { yaşamda iş kolaylığı sağlayacak bir düzenek tasarlar. }\end{array}$ & $2,4,8,10,12,13$ \\
\hline \multicolumn{2}{|c|}{$\begin{array}{l}\text { Tablo } 2 \text { incelendiğinde, Fen Bilimleri Dersi Öğretim Programı'ndaki (MEB, 2018) "basit makineler" } \\
\text { ünitesindeki birinci kazanımın } 18 \text { maddenin 12'si ile ilgili olduğu; ikinci kazanımın ise } 18 \text { maddenin } \\
\text { 6'sı ile ilgili olduğu belirlenmiştir. İkinci kazanımda öğrencilerden düzenek tasarlamaları istenmektedir. } \\
\text { Ancak çoktan seçmeli testler her hangi bir düzenek tasarlamak ve bunu çizimle göstermek için uygun } \\
\text { değildir. Bu bakımdan günlük yaşamda iş kolaylığı sağlayan basit makinelere odaklanılmış bu bağlamda } \\
\text { test maddeleri hazırlanmıștır. }\end{array}$} \\
\hline
\end{tabular}


“F.8.5.1.1. Basit makinelerin sağladı̆̆ı avantajları örnekler üzerinden açıklar.” Kazanımına ilişkin örnek sorular:

Soru 6. Şekildeki eşit bölmeli, ağırlı̆̆ önemsenmeyen çubuk, içlerinde su bulunan $\mathrm{K}$ ve L kaplart ile yatay konumda dengededir.

\section{Aşağıdaki işlemlerden kaçının yapılması halinde denge bozulur?}

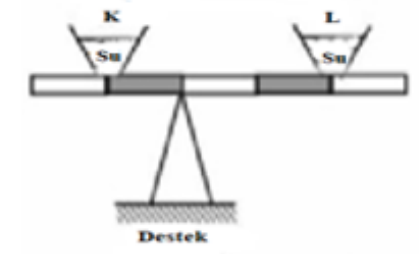

- Kaplara eşit miktarlarda su eklenmesi

- Kaplardan eșit miktarlarda su alınması

- K kabını yerine L, L kabının yerine K kabının konulması

- Kapların eșit mesafede desteğe yaklaştırılması
a) Birinin
b) İkisinin
c) Üçünün
d) Dördünün

Soru 7. Așağıdaki kaldıraçlardan hangisi, yükü yukarı kaldırmak için uygulanması gereken kuvvetin hem yönünü hem de büyüklüğünü değiştirmiștir? (Kaldıracın ağılığını ihmal ediniz.

A)

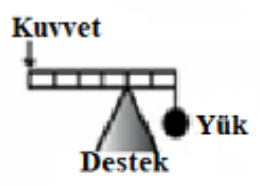

B)



C)

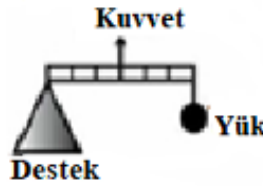

D)

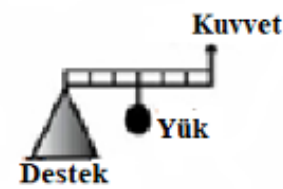

Soru 15.

- Terzi makası

- Kerpeten

- Maşa

- El arabası

- Pense

- Tahterevalli

- Terazi

Yukandakilerden kaç tanesi destek noktası ortada olan kaldıraca örnektir?

a) 2

b) 4

c) 5

d) 7

Soru 17. K cismi, özdeș ve ağırlığı önemsenmeyen ip ve makaralardan oluşmuş șekildeki bileșik makinelerle en küçük $F_{1}, F_{2}$ ve $F_{3}$ kuvvetleri ile yukarı doğru çekiliyor.

Buna göre, kuvvetler arasındaki ilișki aşağıdakilerin hangisinde doğru verilmiștir?
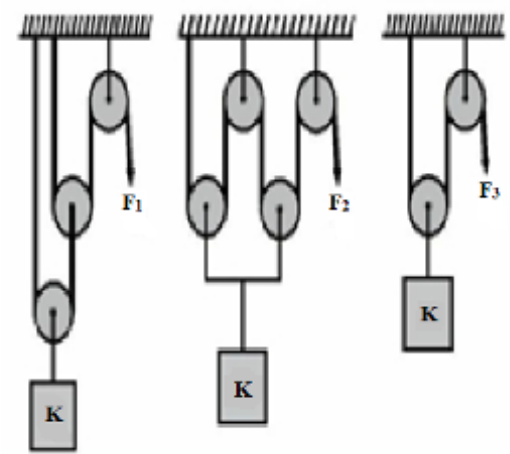
a) $\mathrm{F}_{1}=\mathrm{F}_{2}=\mathrm{F}_{3}$
b) $\mathrm{F}_{3}<\mathrm{F} 1=\mathrm{F}_{2}$
c) $\mathrm{F}_{1}=\mathrm{F}_{2}<\mathrm{F}_{3}$
d) $\mathrm{F}_{2}<\mathrm{F}_{1}<\mathrm{F}_{3}$ 
"F. 8.5.1.1.a. Basit makinelerden, sabit makara, hareketli makara, palanga, kaldıraç, eğik düzlem ve çırılk üzerinde durulur." kazanımına ilişkin örnek sorular:

Soru 4. Bir öğrenci yanda ağırlığı önemsenmeyen eşit bölmeli, homojen çubuğa asılı $\mathrm{K}$ ve $\mathrm{L}$ boş kovalarını dinamometre ile $\mathrm{O}$ noktasından kaldırdığında çubuğun yatay konumda kaldığını görüyor.

Öğrenci bu deneyle aşağıdaki sonuçlardan hangisine ulaşamaz?

a) O noktası sistemin denge noktasıdır.

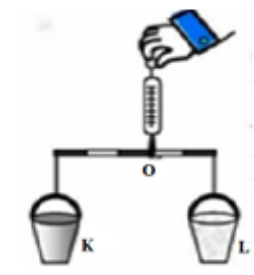

b) $\mathrm{K}$ kovası $\mathrm{L}$ kovasından daha ağırdır.

c) Dinamometreden okunan değer $\mathrm{K}$ ve $\mathrm{L}$ kovalarının ağıllıkları toplamı kadardır.

d) $K$ ve $L$ kovasının kütleleri birbirinden farklıdır.

Soru 5. Makara ağırlı̆ının önemsenmediği Șekil I ve Şekil II sistemleri dengededir.

\section{Buna göre $\mathrm{K}, \mathrm{L}$ ve $\mathrm{M}$ cisimlerinin ağırlıkları hakkında hangisi} söylenir?

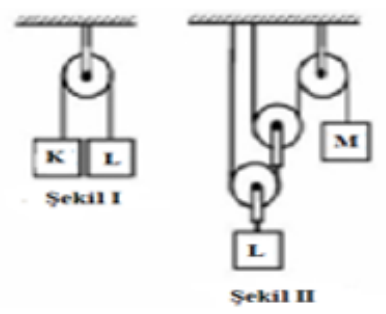
a) $\mathrm{K}>\mathrm{L}>\mathrm{M}$
b) $\mathrm{K}=\mathrm{L}>\mathrm{M}$
c) $\mathrm{K}>\mathrm{L}=\mathrm{M}$
d) $\mathrm{K}=\mathrm{L}=\mathrm{M}$

Soru 9. Ali, bir demir küreyi kütlesi önemsiz ve eşit bölmeli bir kaldıraç ile aşağıdaki gibi dört farklı durumda kaldırıyor.
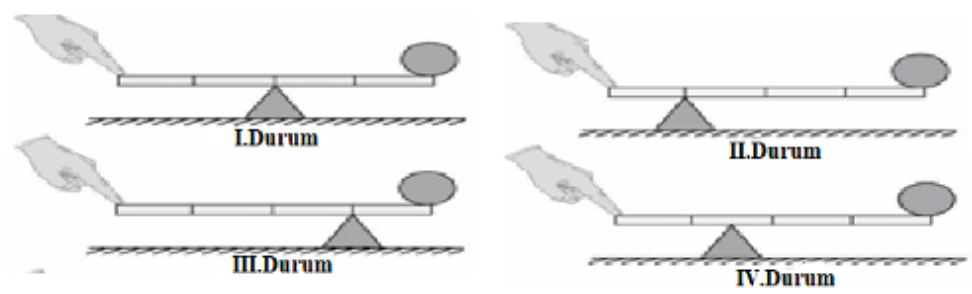

Buna göre Ali, hangi durumda giriş (uygulanan), kuvvetinden daha büyük bir çıkış (doğan) kuvveti elde etmiştir?
a) I
b) II
c) III
d) IV

Soru 11. Așağıdaki șekillerde verilen kaldıraçların hangisinde yatay konumda denge sağlanamaz? (Çubukların ağılığı önemsizdir).

A)

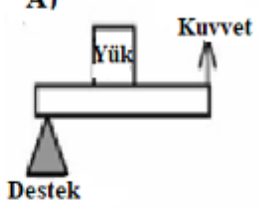

B)



C)

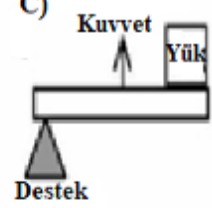

D)

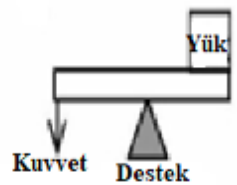


Soru 14. Şekildeki $\mathrm{K}$ cismini kaldırabilmek için ağırlığı önemsenmeyen çubuğa uygulanan en küçük kuvvet $\vec{F}$ olduğuna göre aşağıdakilerden hangisi yanlıștır?

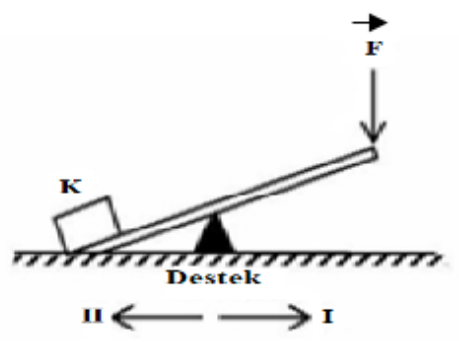

a) Destek II yönünde kaydırıldığında, $\mathrm{K}$ cismi $\vec{F}$ 'den daha küçük bir kuvvetle kaldırılabilir.

b) $\mathrm{K}$ cismi, I yönünde kaydırıldığında, $\vec{F}$ kuvveti $\mathrm{K}$ cismini kaldırabilir.

c) Destek, I yönünde kaydırıldığında $\mathrm{K}$ cismi $\vec{F}$ kuvveti ile kaldırılamaz.

d) K'nın üzerine bir cisim konulup destek, I yönünde kaydınıldığında, $\mathrm{K}$ ve üzerindeki cisim $\vec{F}$ kuvveti ile kaldırılabilir.

"F.8.5.1.1.b. Dişli çarklar, vida ve kasnakların da birer basit makine olduğu görsellerle belirtilir, ayrıntıya girilmez." kazanımına ilişkin örnek sorular:

Soru 3. K dişlisi ok yönünde 3 tur çevrildiğinde L kasnağının görünüşü şekildeki gibi oluyor.

Buna göre L kasnağının bașlangıçtaki durumu
hangisinde verilmiștir?
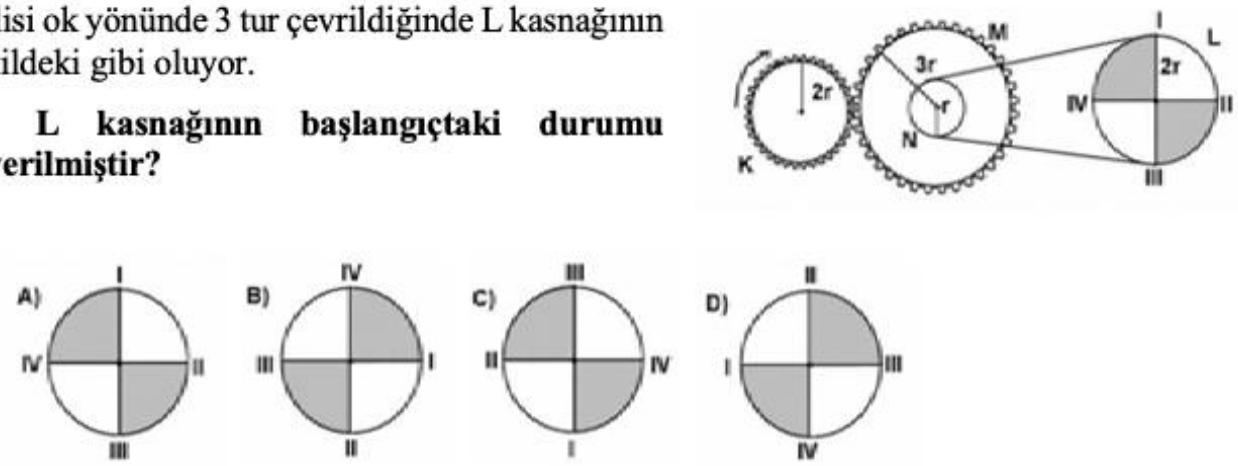

Soru 18. Şekildeki sistemde $\mathrm{R}$ dișlisi gösterilen yönde bir dolanım yaptığında, $P$ dişlisinin görünümü aşadakilerden hangisindeki gibi olur?

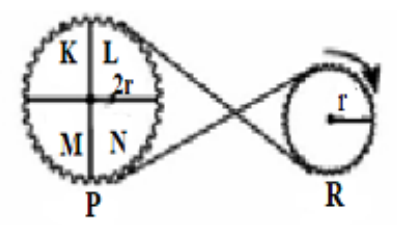

A)

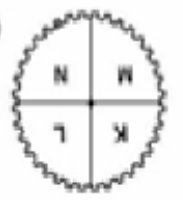

B)

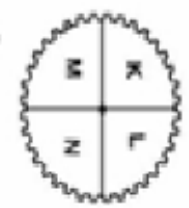

C)

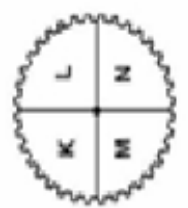

D)

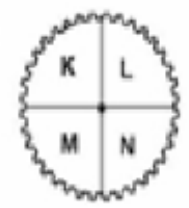


Soru 16.

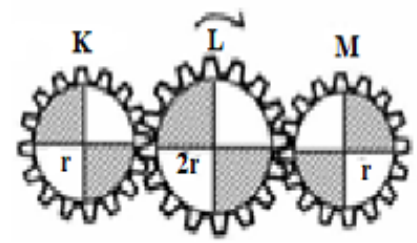

Şekildeki $K$, $L$ ve $M$ dişlilerinden oluşan sistemde $L$ dişlisi ok yönünde 2,5 tur dödürülürse, $K$ veM dişlilerinin son durumu nasıl olur?
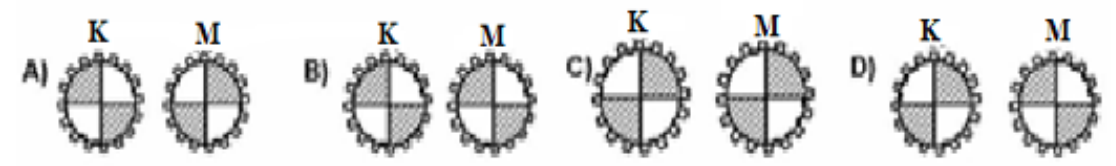

“F.8.5.1.1.c. Basit makinelerde işten kazanç olmadığı vurgulanır.” kazanımına ilişkin örnek sorular:

Soru 1. Aşağıdakilerden hangisi yükü ortada olduğu kaldıraca örnektir?
a) El arabasi
b) Soba mașası
c) Kürek
d) Kerpeten

Soru 10. Așağıdaki olaylar çeşitli kaldıraç prensiplerine örnek olarak gösterilebilir. Bunlardan seçeneklerde verilenlerden hangi ikisi aynı kaldırac prensibine örnektir?

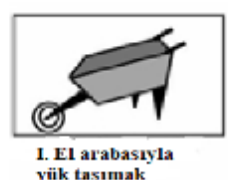

a) I-III

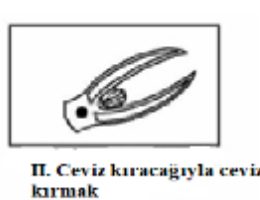

b) I-IV

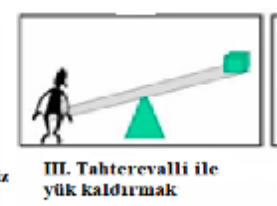

c) II-III

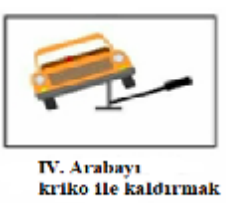

d) III-IV

"8.5.1.2. Basit makinelerden yararlanarak günlük yaşamda iş kolaylı̆ğ sağlayacak bir düzenek tasarlar.” kazanımına ilişkin örnek sorular:

Soru 2. Şekildeki eşit bilmeli tahterevallinin P noktasında oturan $15 \mathrm{~kg}$ ağırlığındaki Okan denge konumuna getirilmek istenmektedir. Buna göre aşağıdakilerin hangisinde denge sağlanmaz?

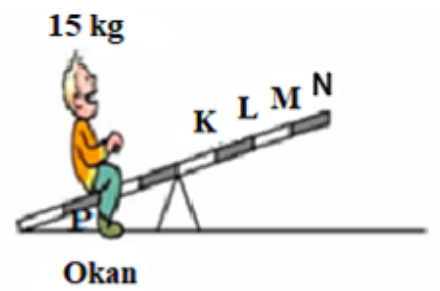

a) K'ye $30 \mathrm{~kg}$ ağırlığındaki Ziya oturduğunda

b) L'ye $15 \mathrm{~kg}$ ağırlığındaki Göktuğ oturduğunda

c) M'ye $10 \mathrm{~kg}$ ağırlı̆̆ındaki Selim oturduğunda

d) N'ye $20 \mathrm{~kg}$ ağırlığındaki Hakan oturduğunda 
Soru 8. Bir tahterevallide aşağıdaki şekilde görüldüğü gibi sırasıyla dengede olan Ayșe, Okan ve Mehmet'in kütleleri nasıl sıralanır?

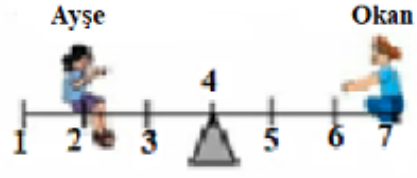

a) Okan $>$ Ayşe $>$ Mehmet

c) Mehmet $>$ Ayşe $>$ Okan

Soru 12. Kapalı kaptaki buzun erimesi sirasında, şekildeki eșit kollu terazide aşağıdaki durumlardan hangisi gözlenir?

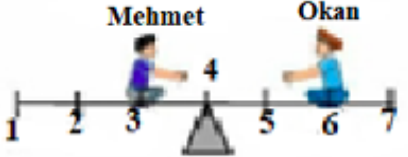

b) Okan $>$ Mehmet $>$ Ayșe

d) Mehmet $>$ Okan $>$ Ayşe

a) Denge durumunun korunmasi

b) Sol kefenin yukarı doğru hareket etmesi

c) Sağ kefenin yukarı doğru hareket etmesi

d) Sol kefenin önce aşağıya sonra yukarı doğru hareket etmesi

Soru 13. Öğretmen öğrencilerine, "Bana öyle bir makara sistemi hazırlayın ki bu sistem, uyguladığım kuvveti K cismine zıt yönde iletsin." diyor. Öğrenciler de aşağıdaki düzenekleri hazırlıyorlar (Sürtünme kuvveti ihmal edilmiștir).

\section{Hangisi öğretmenin istediği düzenektir?}
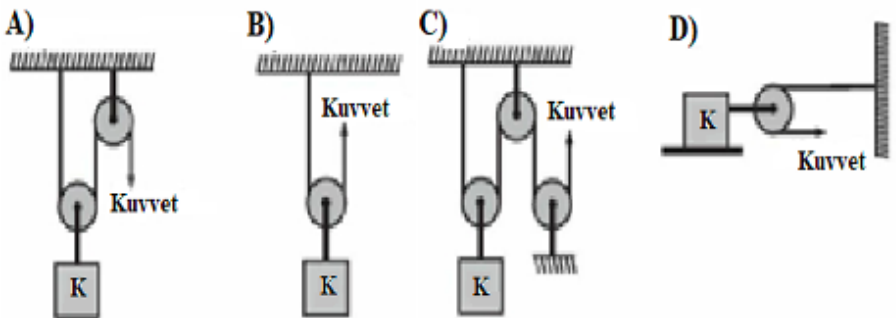

\section{Testin Ölçülecek Özelliklerinin Belirlenmesi}

Testin ölçülecek özellikleri alanyazın incelemesi ve çeşitli kaynakların incelenmesi (ulusal testler, ders kitapları vb.) aracılığıyla gerçekleştirilmiştir. Maddelerin yazımını geçmeden ulusal çapta yapılmış sinavlarda ("Devlet Parası Yatıl11k Sinav1 (DPY)", "Seviye Belirleme Sinav1 (SBS)", "Parasız Yatıl1 ve Bursluluk Sınavı (PYBS)" ve "Ortaögretim Kurumları Sınavı (OKS)") çıkan basit makineler ünitesiyle ilgili çoktan seçmeli sorular incelenmiştir. Bu sorulara dikkat edilerek hazırlanan testin geliştirilmesinde her bir kazanıma ilişkin en az iki soruya yer verilmesine (Webb, 1997) dikkat edilmiş ve kazanım soru ilişkisi belirtke tablosu (Tablo 2) aracılığılla verilmiştir. 


\section{Maddelerin Yazımı}

Testi oluşturacak maddenin yazımında: Ölçme aracında kullanılacak soru türünün ölçülecek davranış1 ölçmeye uygun olması, seçilen sinav türüne uygun olarak soru sayısı ve içeriğinin belirlenmesi ve soruların belirtke tablosunda (Tablo 2) yer alan davranışları yoklaması (Baykul, 2015; Crocker ve Algina, 1986; Tan, 2015) gibi özelliklere dikkat edilmiştir. Bu doğrultuda, bu araştırmada kazandırılmak istenilen davranışı öğrencilerin kazanma düzeylerini belirlemek üzere başarı testlerinden (Tan, 205) yararlanılmıştır. Yanıt anahtarı önceden belirlenmiş, kolay puanlanabilen ve analiz edilebilen, puanlamasına hata karıştırmayan objektif test türlerinden bir tanesi olduğu için çoktan seçmeli testlerden (Doğan, 2009) yararlanılmıştır. Aynı zamanda çoktan seçmeli testler Klasik Test Teorisi'ne uygun olarak "0-1" puanlama yöntemine uygundur ve tek boyutlu bir özelliği ölçmektedir (Tan, 2015). Madde yazımında soruların belirtke tablosunda (Tablo 2) belirtilen davranışları yoklamasına dikkat edilmiş ve kapsam geçerliğine dikkat edilmiştir. Ayrıca maddelerin yazımında ulusal çapta yapılmış sınavlardan yararlanılmış ve bu soruların yazımı ve incelemesinde alan uzmanlarının görüşlerine başvurulmuştur. Benzer şekilde soru sayısı ve dağılımı belirlenirken uzman görüşleri ve alan sınavlarındaki dağılımdan yararlanılmış ve testteki maddelerin kazanımları kapsamasına dikkat edilmiştir. Testin amacının belirlenmesi ve testte ölçülecek özelliklerin belirlenmesi bölümünde detaylar verilmiştir.

Alanyazın ve kaynakların incelenmesi sonrasında, basit makineler ünitesinin "makaralar, kaldıraçlar ve dişli çarklar" konularıyla ilgili olarak Fen Bilimleri Dersi Öğretim Programı'ndaki (MEB, 2018) "basit makineler" ünitesinin kazanımlarını içeren toplam 25 çoktan seçmeli soru yazılmıştır.

\section{Madde Redaksiyonu}

Madde redaksiyonu, testin kapsam ve görünüş geçerliğini, soruların bilimsel açıdan doğruluğunu, dil bakımından anlaşılırlığını, dilbilgisi bakımından yeterliliğini ve sorularda teknik bakımından hata bulunup bulunmadığına ilişkin yapılan kontrolleri içermektedir (Baykul, 2015; Crocker ve Algina, 1986; Tunç ve K1lınç Alpat, 2015).

BMÜABT'nin maddeleri alanyazında sklıkla ifade edildiği gibi uzman görüşü doğrultusunda incelenmiştir (Atılgan, 2009; Baykul, 2015; Çalık ve Ayas, 2003). Araştırmanın uzmanlarını alanında uzman iki fen bilgisi öğretmeni ile fen bilgisi eğitimi alanında görev yapan bir öğretim üyesi ve Türkçe eğitimi alanında görev yapan bir dilbilgisi uzmanı öğretim üyesi oluşturmaktadır. Uzman görüşleri sonrasında kapsam geçerliği bakımından uygun olmadığı belirlenen beş madde testten çıkarılmış ve 20 maddelik çoktan seçmeli sorudan oluşan taslak form oluşturulmuştur.

\section{Deneme (Taslak) Formunun Hazırlanmast}

Testin pilot uygulaması üç aşamalı bir uygulama ile gerçekleştirilmiştir. İlk aşamada, pilot testin uygulanacağ 1 deneme grubu belirlenmiştir. İkinci aşamada, deneme formu hazırlanmıştır. Üçüncü aşamada ise deneme uygulaması gerçekleştirilmiştir. Pilot testin uygulanacağ 1 deneme grubu belirlenirken, bu grubun testin uygulanacağı gruba benzer nitelikteki öğrencilerden oluşmasına dikkat edilmiştir. Bu doğrultuda aynı okulda aynı sınıf düzeyinde öğrenimine devam eden sekizinci sınıf öğrencileri oluşturmuş̧tur. Pilot testin uygulanacağ 1 deneme grubu Aksaray ili merkez ilçesinde bir devlet ortaokulunda öğrenimine devam eden "basit makineler" ünitesini işlemiş 24 sekizinci sınıf öğrencisinden oluşmaktadır. Deneme grubunun öğrencileri testin uygulanacağı esas gruba benzer özelliklere sahiptir. Ayrıca bu öğrenciler ortalama akademik başarı düzeyindedir. Deneme formunun hazırlanmasında ise soruların yerleşiminde tesadüfi dağılım yöntemi esas alınırken, formun yazılmasında MEB'in ders kitapları için kabul ettiği standart harf ve büyüklükler kullanılmıştır (10 punto) (MEB, 2020b) ve teste ilişkin yönerge hazırlanmıştır. Deneme maddelerinin yazımı testin amacının belirlenmesi, testin ölçülecek özelliklerinin belirlenmesi ve madde yazımı bölümlerinde detaylı olarak açıklanmıştır. Deneme testinin uygulaması nihai testin uygulamasından önce sınıf ortamında, sınav koşullarına uygun olarak gerçekleştirilmiştir.

\section{Pilot Test Uygulamast}

Deneme formunun oluşturulması sonrasında hazırlanan 20 çoktan seçmeli sorudan oluşan BMÜABT'nin pilot uygulaması 24 öğrenci ile gerçekleştirilmiştir. Deneme uygulaması sırasında öğrencilerin sınav koşullarına uyması sağlanırken, sınav ortamında gerekli düzenlemeler yapılmış ve testin amacı öğrencilere açıklanarak içsel motivasyonları sağlanmıştır. Pilot test uygulaması sonucunda öğrencilerin sınav sorularına ilişkin görüşleri alınmış; anlaşılmayan, yanlış anlaşılan, okunması zor olan 
sorularda düzenleme yapılmıştır. Bu doğrultuda birinci maddenin seçeneklerinde yer alan kargaburnu çıkartılmış ve yerine kerpeten seçeneği eklenmiştir.

\section{Nihai Testin İstatistiklerinin Kestirilmesi: Madde Puanlanması, Madde Analizi ve Madde Seçimi}

Pilot test uygulaması sonrasında düzenlenen 20 çoktan seçmeli sorudan oluşan BMÜABT testin istatistiklerini kestirmek üzere 160 sekizinci sınıf öğrencisine uygulanmıştır. Bu uygulama sırasında öğrencilerin sınav koşullarına uyması sağlanırken, sınav ortamında gerekli düzenlemeler yapılmış ve testin amacı öğrencilere açıklanarak içsel motivasyonları sağlanmıştır.

Testin geçerlik ve güvenirliği "Excel" ve "SPSS (Statistical Package for the Social Sciences (Sosyal Bilimler İçin İstatistik Programı))" programlarından yararlanılarak gerçekleştirilmiştir. Yapılan madde güçlük ve madde ayırt edicilik analizi sonucunda, madde ayırt edicilik indeksi 0,19 ve daha küçük olan (Ebel, 1965'ten aktaran Crocker ve Algina, 1986; Baykul, 2015) iki madde (Madde 19: rjx=.12, p=.78; Madde 20: $\mathrm{rjx}=.16, \mathrm{p}=.76$ ) test kapsamından çıkarılmış ve testin nihai istatistikleri 18 çoktan seçmeli sorudan oluşan BMÜABT ile gerçekleştirilmiştir.

Madde puanlamasında Klasik Test Teorisi'nden yararlanılmışırı (Baykul, 2015). Elde edilen veriler sonucunda doğru cevaplanan maddeler için "1"; yanlış cevaplanan, boş bırakılan veya çift seçenek işaretlenen maddeler ise "0" olarak puanlanmıştır.

Testin güvenirliği KR-21 iç tutarlık katsayısı hesaplanarak belirlenmiştir. Teste konulması düşünülen maddelerin seçimi amacıyla madde analizi yapılmıştır. Bu araştırmada madde analizleri "madde güçlük indeksi (pj)" ve "madde ayırt edicilik indeksi (rjx)" aracılığıyla yapılmıştır.

Madde puanlarının dağılımını betimleyen, diğer bir tanımla doğru cevaplayanların yüzdesi olarak adlandırılan "madde güçlük indeksi" [0,1] aralığında değer alabilir (Atılgan, 2009; Baykul, 2015; Tekin, 2010). Madde güçlük indeksinin değerlendirilmesinde: Doğru cevaplayan sayısı arttıkça madde güçlük indeksi 1'e yaklaşarak ve madde kolaylaşırken; tersine doğru cevaplayanların sayısı azaldıkça ise madde madde güçlük indeksi 0'a yaklaşacak ve madde zorlaşacaktır. Standart bir başarı testinde ortalama madde güçlük indeksinin 0,50 seviyesinde olması beklenmektedir (Baykul, 2015; Tekin, 2010).

Madde ayırt edicilik indeksi ise "madde puanları ile test puanları arasındaki korelasyon olarak tanımlanır" (Baykul, 2015). Madde ayırt ediciliğinin değerlendirilmesinde aşağıdaki ölçütler kullanılmaktadır. Madde ayırt edicilik indeksinin 0,19 ve daha küçük bir değer alması bu maddenin testten çıkarılmasına neden olur. Madde ayırt edicilik indeksinin [0,20-0,30] arasında olması madde ayırt ediciliğinin düşük olduğunu, gözden geçirilerek teste eklenebileceğini; [0,31-0,40] arasında olmas1 madde ayırt ediciliğinin iyi olduğunu; 0,40'ın üzerinde olması madde ayırt ediciliğinin çok iyi olduğunu ifade etmektedir (Ebel, 1965'ten aktaran Crocker ve Algina, 1986; Baykul, 2015; Tekin, 2010).

Madde analizi sonrasında, başarı testinin kapsam geçerliği ve maddenin ölçmek istediği davranış düşünülerek, kazanımlar doğrultusunda testte kalması düşünülen maddelere karar verilmiştir. Madde seçimi sonrasında, nihai testin istatistiksel kestirimi yapılarak test geliştirme işlemi tamamlanır.

\section{Bulgular}

Nihai BMÜABT’nin 160 öğrenciye uygulanması sonucunda elde edilen bulgular bu bölümde detaylı olarak sunulmuştur. Geliştirilen BMÜABT'ye konulması düşünülen maddeleri belirlemek amacıyla madde ayırt edicilik indeksi (rjx) ve madde güçlük indeksi (p) hesaplanarak madde analizi gerçekleştirilmiştir. BMÜABT'nin madde analizi sonucunda elde edilen bulgular Tablo 3'te gösterilmiştir.

Tablo 3 incelendiğinde, madde analizine dâhil edilen 18 maddeden 12'sinin madde ayırt edicilik indeksinin 0,40 ve üzerinde olduğu (çok iyi); üç maddenin ayırt edicilik indeksinin 0,31 ile 0,40 arasında olduğu (iyi); kalan üç maddenin ayırt edicilik indeksinin ise 0,21 ile 0,30 arasında olduğu (düşük, gözden geçirilmeli) belirlenmiştir. Bu üç madde incelenmiş ve uzman görüşleri doğrultusunda bu maddelerde değişiklikler yapılmış (örneğin: altıncı soruda seçenekler öncüller halinde düzenlenmiş, onuncu soruya şekiller eklenmiştir) ve bu maddelerin kapsam geçerliğini düşürmemesi açısından teste dahil edilmesine karar verilmiştir. Crocker ve Algina (1986) ile Ebel (1965)'a dayanarak madde ayırt edicilik indeksi madde güçlük indeksi birlikte incelendiğinde iki sorunun madde güçlüğünün yüksek, diğer maddenin de güçlügünün düşük ancak 0,50 seviyesinde olduğu belirlenmiş ve bu maddelerin testte kalmasına karar verilmiştir (Crocker ve Algina, 1986; Ebel, 1965'ten aktaran Crocker ve Algina, 1986). Testin 20 
soruluk ilk madde analizinde yer alan iki madde ise madde ayırt edicilik indeksi 0,19 ve altında olduğu için, testin madde güçlük indeksi değerini iyileştirmek, madde ayırt edicilik indeksi ve KR-21 güvenirlik katsayısını arttırmak için test kapsamından çıkartılmıştır. Testin madde güçlük indeksine bakıldığında ise 18 maddeden 13'ünün madde güçlük indeksinin 0,50 ve üzerinde olduğu; beşinin ise madde güçlük indeksinin 0,50’nin altında olduğu belirlenmiştir.

Tablo 3

BMÜABT Madde Analizi Sonuçları

\begin{tabular}{cll}
\hline Madde numarasi & $\boldsymbol{r}_{\boldsymbol{j} \boldsymbol{x}}$ & $\boldsymbol{p}$ \\
\hline 1 & .21 & .85 \\
\hline 2 & .37 & .72 \\
\hline 3 & .57 & .55 \\
\hline 4 & .57 & .67 \\
\hline 5 & .40 & .78 \\
\hline 6 & .25 & .31 \\
\hline 7 & .51 & .58 \\
\hline 8 & .65 & .56 \\
\hline 9 & .38 & .49 \\
\hline 10 & .30 & .75 \\
\hline 11 & .60 & .46 \\
\hline 12 & .31 & .34 \\
\hline 13 & .59 & .60 \\
\hline 14 & .50 & .39 \\
\hline 15 & .62 & .59 \\
\hline 16 & .65 & .58 \\
\hline 17 & .80 & .55 \\
\hline 18 & .70 & .51 \\
\hline
\end{tabular}

18 çoktan seçmeli maddeden oluşan nihai testin istatistiksel analizleri sonrasında elde edilen bulgular Tablo 4'te verilmiştir.

Tablo 4

BMÜABT İçin Gerçekleştirilen İkinci Aşama Analizine İlişkin Bulgular

\begin{tabular}{ll}
\hline BMÜABT özellikleri & Dĕ̆er \\
\hline Madde sayısı & 18 \\
\hline Uygulamanın yapıldı̆̆ı kişi sayısı & 160 \\
\hline Ortalama & 10,798 \\
\hline Minimum & 0 \\
\hline Maksimum & 18 \\
\hline Standart Sapma & 3,795 \\
\hline Varyans & 14,409 \\
\hline KR-21 & 0,741 \\
\hline$r_{j x}$ & 0,50 \\
\hline$p$ & 0,57 \\
\hline
\end{tabular}

Tablo 4 incelendiğinde, 18 çoktan seçmeli sorudan oluşan BMÜABT'nin toplam 160 sekizinci sınıf öğrencisine uygulandığ 1 belirlenmiştir. Verilerin analizi sonucunda BMÜABT'nin geneli için aritmetik ortalamanın 10,798 (bu değer bu testi oluşturan maddelerin güçlüklerinin toplamını ifade etmektedir (Tan, 2015)); testin geneline ilişkin standart sapma değeri 3,795 ve varyans ise 14,409 bulunmuştur. Standart sapma ve varyans maddenin ve testin güvenirliğinin hesaplanmasında kullanılan değerlerdir. BMÜABT'nin geneli için madde güçlük indeksinin $(\mathrm{p}=0,57)$ "ortalama" güçlükte olduğu belirlenirken; ortalama madde ayırt edicilik indeksinin ise $(\mathrm{rjx}=0,50)$ "çok iyi" $(\mathrm{rjx} \geq 0,40)$ ayırt edicilikte olduğu belirlenmiştir (Ebel, 1965’ten aktaran Crocker ve Algina, 1986; Hasançebi, Terzi ve Küçük, 2020; Tekin, 2010). 
Testin güvenirliğinin 0 ile 1 arasında bir değer alması beklenmektedir. Güvenilir bir başarı testinin

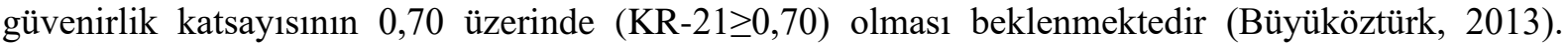
BMÜABT'nin güvenirliğini belirlemek üzere hesaplanan KR-21 güvenirlik katsayıs1 0,741 olarak belirlenmiştir.

BMÜABT'nin kapsam geçerliği uzman görüşü ve belirtke tablosu (Tablo 2) aracilığıyla belirlenmiştir. Araştırmanın uzmanlarını alanında uzman iki fen bilgisi öğretmeni ile fen bilgisi eğitimi alanında görev yapan bir öğretim üyesi ve Türkçe eğitimi alanında görev yapan bir dilbilgisi uzmanı öğretim üyesi oluşturmaktadır. Testin görünüş geçerliği ise hem uzman görüşü hem de 24 sekizinci sınıf öğrencisi ile gerçekleştirilen pilot uygulaması ile gerçekleştirilmiştir. Tablo 4 ve test geliştirme aşamasında elde edilen bulgular incelendiğinde BMÜABT'nin geçerli ve güvenilir bir ölçme aracı olduğu söylenebilir.

\section{Tartışma ve Sonuç}

$\mathrm{Bu}$ araştırmada, ortaokul sekizinci sınıf öğrencilerinin basit makineler ünitesine yönelik akademik başarılarını ölçmek amacıyla çoktan seçmeli sorulardan oluşan geçerli ve güvenilir bir test geliştirilmiştir. Geliştirilen bu test 18 çoktan seçmeli maddeden oluşmaktadır.

BMÜABT'nin madde analizi sonucunda, 18 maddenin madde ayırt edicilik indeksi dağılımının 0,21 ile 0,80 arasında değişirken; ortalama madde ayırt edicilik indeksinin ise 0,50 olduğu belirlenmiştir. Ortalama madde ayırt edicilik indeksi bu testin maddelerinin "çok iyi" (rjx $\geq 0,40$ ) madde ayırt ediciliğine sahip olduğunu göstermektedir (Baykul, 2015; Ebel, 1965'ten aktaran Crocker ve Algina, 1986; Hasançebi, Terzi ve Küçük, 2020). Crocker ve Algina (1986) ile Tekin (2010)'e göre maddeler tek tek incelendiğinde, maddelerin çoğunluğunu madde ayırt ediciliğinin "çok iyi" (12 madde) ve "iyi" (3 madde) olduğu belirlenmiş̧tir. Geriye kalan üç maddenin ise madde ayırt ediciliğinin "düşük" olduğu belirlenmiştir. Madde ayırt ediciliği düşük olan bu maddeler: sorulardan bir tanesinde (altıncı soru) seçenekler öncüller haline getirilerek, diğerinde ise soruya şekiller eklenerek düzenlenmiş, diğer soruda ise alan uzmanlarının görüşü doğrultusunda bir değişiklik yapılmayarak yeniden düzenlenmiş ve teste dahil edilmiştir (Ebel, 1965'ten aktaran Crocker ve Algina, 1986; Baykul, 2015; Tekin, 2010). Hasançebi, Terzi ve Küçük (2020), madde ayırt edicilik indeksi " 0,19 ve daha küçük" olan maddelerin madde ayırt ediciliğinin "çok zayıf" olduğunu ve mutlaka testten çıkarılmasını gerektiğini belirtmektedir. Bu bağlamda BMÜABT’nin madde ayırt ediciliğinin akademik başarı düzeyi yüksek olan öğrenci ile düşük olan öğrenciyi ayırma bakımından yeterli olduğu görülmektedir. Alanyazın incelendiğinde, fen eğitiminde test geliştirme ile ilgili araştırmaların ortalama madde ayırt edicilik indeksi 0,40 üzerinde (çok iyi) olduğu belirlenmiştir (Açıkgöz ve Karslı, 2015; Gönen, Kocakaya ve Kocakaya, 2011, 2011; Gülmez Güngörmez ve Akgün, 2018; Güneş ve Serdaroğlu, 2018; Özcan, vd., 2019; Özkan ve Eryılmaz Muştu, 2018; Şen ve Eryılmaz, 2011; Şener ve Taş, 2017; Demir, Kızılay ve Bektaş, 2016).

BMÜABT'nin madde analizi sonucunda, 18 maddenin madde güçlük indeksi dağılımının 0,31 ile 0,85 arasında değişirken; ortalama madde güçlük indeksinin ise 0,57 olduğu belirlenmiştir. Baykul (2015) ve Tekin (2010)'e göre bir testin ortalama madde güçlük indeksinin 0,50 civarında olması beklenmektedir. BMÜABT'nin madde güçlük indeksi dağılımı $(0,31-0,85)$ ve ortalama madde güçlük indeksi $(0,57)$ "ortalama" düzeydedir. Bu durum BMÜABT’nin “ortalama" güçlükte bir test olduğunu ortaya koymaktadır. Alanyazın incelendiğinde, fen eğitiminde test geliştirme ile ilgili araştırmalarının madde güçlük indeksinin 0,50 civarında olduğu belirlenmiştir (Gülmez Güngörmez ve Akgün, 2018; Nakiboğlu ve Güneş Yazar, 2019).

BMÜABT'nin KR-21 güvenirlik katsayısı 0,741 olarak belirlenmiştir. Büyüköztürk (2013)'e göre bu değer BMÜABT'nin güvenilir bir test olduğunu göstermektedir $(K R-21 \geq 0,70)$. Alanyazın incelendiğinde, fen eğitiminde test geliştirme ile ilgili araştırmaların güvenirlik katsayılarının (KR-20 ve KR-21) bu araştırma sonucuna benzer şekilde 0,70 üzerinde olduğu belirlenmiştir (Çakır ve Aldemir, 2011; Gönen, vd., 2011; İdin ve Aydoğdu, 2016; Özcan, vd., 2019; Tosun ve Taşkesenligil, 2011).

BMÜABT'nin kapsam ve görünüş geçerliği öğretmen ve alan uzmanlarının görüşü kapsamında belirlenmiştir. Kapsam ve görünüş geçerliğinin uzman görüşleri kapsamında belirlenmesi alanyazında sıklıkla ifade edilmektedir (Atılgan, 2009; Çalık ve Ayas, 2003). Ayrıca BMÜABT'nin kapsam geçerliğine ilişkin olarak kazanım soru ilişkisinin yer aldığ1 "belirtke tablosu" (Tablo 2) da hazırlanmıştır. Büyüköztürk vd. (2012) ve Erkuş (2017) kapsam geçerliğini garanti altına almak için 
belirtke tabloları veya iş analizlerinin yapılması gerektiğini belirtmişlerdir. Alanyazın incelendiğinde, fen eğitiminde test geliştirme ile ilgili araştırmalarda bu araştırmaya benzer şekilde uzman görüşünden yararlanıldığı ve belirtke tablolarının hazırlandığı görülmektedir (Açıkgöz ve Karslı, 2015; Gülmez Güngörmez ve Akgün, 2018; Nakiboğlu ve Güneş Yazar, 2019; İdin ve Aydoğdu, 2016; Akbulut ve Çepni, 2013; Özkan ve Eryılmaz Muştu, 2018).

Araştırma sonucunda, ortaokul sekizinci sınıf öğrencilerinin basit makineler ünitesine yönelik akademik başarılarını ölçmek amacıyla 18 çoktan seçmeli sorudan oluşan geçerli ve güvenilir BMÜABT geliştirilmiştir ( $\mathrm{X}^{-}=10,798$; s=3,795; s2=14,409; KR-21=0,741). Madde analizi sonucunda elde edilen madde güçlük ve madde ayırt edicilik indeksleri BMÜABT'nin akademik başarı testi olarak kullanılabileceğini göstermektedir (Ort. rjx=0,50; Ort. pj=0,57). BMÜABT, basit makineler ünitesinin kazanımlarıyla uyumlu, güvenilir ve geçerli bir testtir. Bu bağlamda, Klasik Test Teorisi'nin aşamaları (Crocker ve Algina, 1986; Haladyna, 1994, 1997) dikkate alınarak hazırlanan BMÜABT'ın sekizinci sınıf öğrencilerinin basit makineler ünitesine yönelik akademik başarılarını ölçmek amacıyla kullanılabileceği söylenebilir.

\section{Öneriler}

$\mathrm{Bu}$ araştırma kapsamında araştırmacılara şu önerilerde bulunulabilir:

- Bu araştırmada, "basit makineler" ünitesine yönelik olarak akademik başarı testi geliştirilmiştir. $\mathrm{Bu}$ test öğrencilerin akademik başarılarını belirlemek üzere başarı ve düzey belirleyici olarak erişi, izleme ve hazırbulunuşluk testi olarak kullanılabilir. Bu test ders veya kurs sonunda kazandırılması düşünülen başarının ölçülmesi amacıyla "erişi testi”, ders veya kurs sürecinde kazandırılması düşünülen davranışlarının ne kadarının kazandırıldığını ölçmek amacıyla "izleme testi” ve ders veya kurs başlamadan öğrencinin kazandırılması düşünülen davranışlarının ne kadarına sahip olduğunu belirlemek amacıyla "hazırbulunuşluk testi” olarak uygulanabilir. Ancak bu test öğrencilerin genel yeteneklerini belirlemeye uygun değildir. Öğrencilerin ikinci kazanımda yer alan tasarım becerilerini belirlemek amacıyla süreç değerlendirmeye yönelik kabiliyet veya zekâ testleri geliştirilebilir. Ayrıca sekizinci sınıf öğrencilerinin "basit makineler" ünitesine yönelik kavramsal anlamalarını ve kavram yanılgılarını belirlemeye yönelik iki aşamalı veya üç aşamalı bir test geliştirilmesi önerilmektedir.

- BMÜABT başarı ve düzey belirleyici olarak kullanılabilir. Ancak biçimlendirici (formative) değerlendirmeye uygun değildir. $\mathrm{Bu}$ bağlamda "basit makineler" ünitesine yönelik biçimlendirici değerlendirmeye uygun testler geliştirilebilmesi önerilmektedir.

- BMÜABT çoktan seçmeli testlerin avantajları göz önüne alınarak çoktan seçmeli maddelerden oluşan bir test olarak geliştirilmiştir. Özellikle performans değerlendirmeye uygun ölçme ve değerlendirme yöntemleri kullanılabilecek testlerin geliştirilmesi önerilebilir.

- BMÜABT fen bilimleri dersi "basit makineler" ünitesine yönelik olarak geliştirilmiştir. Fen bilimleri dersinin diğer ünitelerine yönelik çeşitli testler geliştirilmesi önerilebilir.

\section{Kaynakça}

Acar, B., Korkmaz, Ö., Çakır, R., Erdoğmuş, F. U., \& Çakır, E. (2019). Eğitsel robot setleri ile fen ve teknoloji dersi basit makinalar konusunun ortaokul 7. sınıf öğrencilerinin STEM beceri düzeylerine ve derse dönük tutumlarına etkisi. Eğitim Teknolojisi Kuram ve Uygulama, 9(2), 372-391.

Açıkgöz, M., \& Karslı, F. (2015). Alternatif ölçme-değerlendirme yaklaşımları kullanılarak iş ve enerji konusunda geliştirilen başarı testinin geçerlilik ve güvenirlik analizi. Amasya Üniversitesi Eğitim Fakültesi Dergisi, 4(1), 1-25.

Adıgüzel, A., \& Sağlam, M. (2009). Öğretmen eğitiminde program standartları ve akreditasyon. İnönü Üniversitesi Ĕ̈itim Fakültesi Dergisi, Özel Sayı 10(3), 83-103. 
Akbaş, A., \& Almalı, S. (2018). Ortaokul 8. sınıflar basit makineler ünitesine köy enstitüleri örneklerinin yansımaları. Dicle Üniversitesi Ziya Gökalp Eğitim Fakültesi Dergisi, (34), 1-21. doi: 10.14582/DUZGEF.1905.

Akbulut, H. İ., \& Çepni, S. (2013). Bir üniteye yönelik başarı testi nasıl geliştirilir? İlköğretim 7. sınıf kuvvet ve hareket ünitesi. Amasya Üniversitesi Ë̆itim Fakültesi Dergisi, 2(1), 18-44.

Almalı, S. (2017). Ortaokul 8. Sinıflar basit makineler ünitesine köy enstitüleri örneklerinin yansıması. Yayımlanmamış yüksek lisans tezi. Mersin Üniversitesi, Mersin, TR.

Arık, S. (2017). Yapılandırmacı öğrenme yaklaşımı ve aktif öğrenmenin çevre eğitimi üzerindeki etkisinin sistematik incelenmesi ve meta-analizi. Yayımlanmamış doktora tezi. Gazi Üniversitesi, Ankara, TR.

Atılgan, H. (2009). Test geliştirme. H. Atılgan (Ed.). Eğitimde ölçme ve değerlendirme içinde (ss. 315348). Ankara: An1.

Avcı, D. E., Kara, İ., \& Karaca, D. (2012). Fen bilgisi öğretmen adaylarının iş konusundaki kavram yanılgıları. Pamukkale Üniversitesi Ĕgitim Fakültesi Dergisi, 31(1), 27-39.

Ayazgök, B. (2013). Basit makineler konusunun dayandığı fizik ilkeleri hakkındaki ilköğretim 7. sınıf ögrencilerinin akademik başarı düzeyleri ile bilişötesi farkındalık düzeylerinin incelenmesi. Yayımlanmamış yüksek lisans tezi. Gazi Üniversitesi, Ankara, TR.

Aytekin, A. (2018). Ortaokul 5. sinıf fen bilimleri dersi ışı̆̆ın ve sesin yayllması ünitesine yönelik geliştirilen materyal ve deney etkinliklerinin ögrrenci akademik başarlsı ve motivasyonuna etkisinin incelenmesi. Yayınlanmamış yüksek lisans tezi. Kocaeli Üniversitesi, Kocaeli.

Ayvacı, H. Ş., \& Durmuş, A. (2016). Bir başarı testi geliştirme çalışması: Isı ve sıcaklık başarı testi geçerlik ve güvenirlik araştırması. Ondokuz Mayıs Üniversitesi Eğitim Fakültesi Dergisi, 35(1), 87-102.

Baykul, Y. (2015). Eğitimde ve psikolojide ölçme: Klasik test teorisi ve uygulaması. Ankara: Pegem Akademi.

Bilgin, A. K., \& Kala, N. (2018). Fen bilimleri konularının günlük hayattaki yeri dersinin öğretmen adaylarının kavram ile bağlam ilişkisini oluşturabilmeleri üzerine etkisi. ERPA 2018, 70.

Büyüköztürk, Ş. (2013). Sosyal bilimler için veri analizi el kitabı istatistik, araştırma deseni SPSS uygulamalart ve yorum. Ankara: Pegem Akademi.

Crocker, L., \& Algina, J. (2008). Introduction to classical and modern test theory. Mason, Ohio: Cengage Learning.

Çakır, M., \& Aldemir, B. (2011). İki aşamalı genetik kavramlar tanı testi geliştirme ve geçerlik çalışması. Mustafa Kemal Üniversitesi Sosyal Bilimler Enstitüsü Dergisi, 8(16), 335-353.

Çalık, M., \& Ayas, A. (2003). Çözeltilerde kavram başarı testi hazırlama ve uygulama. Pamukkale Üniversitesi Eğitim Fakültesi Dergisi, (14), 1-17.

Çelik, S. Ö. (2015). 7. sinuf basit makineler konusunun film ve çizgi filmler ile öğretiminin tutuma ve akademik başarlya etkisi. Yayımlanmamış yüksek lisans tezi. Erzincan Üniversitesi, Erzincan, TR.

Çetinkaya, İ. (2019). Basit makineler ünitesi ile ilgili geliştirilen düşünce deneyi etkinliklerinin 8. sınıf ögrencilerinin kavramsal anlamalarına etkisi. Yayımlanmamış yüksek lisans tezi. Aksaray Üniversitesi, Aksaray, TR.

Demir, N., \& Akarsu, B. (2014). Modern fizik konuları ile ilgili kavram testi geliştirilmesi ve uygulanmas1: Modern fizik kavram testi (MKFT). Journal of European Education, 4(2), 39-51. 
Demir, N., Kızılay, E., \& Bektaş, O. (2016). 7. sınıf çözeltiler konusunda başarı testi geliştirme: Geçerlik ve güvenirlik çalışması. Necatibey Eğitim Fakültesi Elektronik Fen ve Matematik Eğitimi Dergisi, 10(1), 209-237.

Demirel, Ö. (2005). Öğretimde planlama ve değerlendirme: Öğretme sanatı (8. bs.). Ankara: Pegem A.

Diken, E. H. (2018). Fen bilgisi öğretmenleri ile 8. sınıf öğrencilerinin Temel Eğitimden Ortaöğretime Geçiş (TEOG) sınavındaki kaygılarına yönelik görüşleri (Kars ili örneği). İnsan ve Toplum Bilimleri Araştırmaları Dergisi, 7(2), 718-741.

Doğan, N. (2009a). Ölçme araçlarını sınıflama çabaları. H. Atılgan (Ed.). Eğitimde ölçme ve değerlendirme içinde (ss. 119-144). Ankara: Anı.

Doğan, N. (2009b). Çoktan seçmeli testler. H. Atılgan (Ed.). Eğitimde ölçme ve değerlendirme içinde (ss. 223-268). Ankara: An1.

Ennis, R. H. (1985). A Logical basis for measuring critical thinking skills. Educational Leadership, 43 (2), 44-48.

Erkol, M., Kışoğlu, M., \& Gül, Ş. (2017). Argümantasyon tabanlı bilim öğrenme yaklaşımı rapor formatının öğretmen adaylarının başarılarına ve fen bilgisi laboratuvarına yönelik tutumlarına etkisi. Illköğretim Online, 16(2), 614-627.

Erkuş, A. (2017). Davranış bilimleri için bilimsel araştırma süreci (5. Baskl). Ankara: Seçkin.

Field, J. (2001). Lifelong education. International Journal of Lifelong Education, 20(1-2), 3-15.

Flavell, J. H. (1979). Metacognition and cognitive monitoring: A new are of cognitive - development inquiry. American Psychologist, 34(10), 906-911.

Gönen, S., Kocakaya, S., \& Kocakaya, F. (2011). Dinamik konusunda geçerliği ve güvenirliği sağlanmış bir başarı testi geliştirme çalışması, Yüzüncü Yıl Üniversitesi, Eğitim Fakültesi Dergisi, 8(1), 40-57.

Gronlund, N. (1985) Measurement and evaluation in teaching. New York: MacMillan.

Güler, N. (2013). Eğitimde ölçme ve değerlendirme, (5. Bask1). Ankara: Pegem A.

Gülmez Güngörmez, H., \& Akgün, A. (2018). Ortaokul öğrencilerinin fen bilimleri dersindeki kuvvet ve enerji ünitesine yönelik akademik başarı testi geliştirme çalışması. Diyalektolog, (18), 85-99.

Güneş, M. H., \& Serdaroğlu, C. (2018). Bitki ve hayvanlarda üreme, büyüme ve gelişme ünitesinde geliştirilen başarı testinin geçerliliği ve güvenirliği. Bilim, Ĕgitim, Sanat ve Teknoloji Dergisi (BEST Dergi), 2(1), 35-40.

Güneş, T., Dilek, N. Ş., Demir, E. S., Hoplan, M., \& Çelikoğlu, M. (2010). Öğretmenlerin kavram ögretimi, kavram yanılgılarını saptama ve giderme çalışmaları üzerine nitel bir araştırma. International Conference on New Trends in Education and Their Implications (11-13 Kasim 2010), Samsun, TR.

Haladyna, T. M. (1994). Developing and validating multiple choice test items. Hishalde: Lawrence Erlbaum Associates.

Haladyna, T. M. (1997). Writing test items to evaluate higher order thinking. Needham Heights: Allyn \& Bacon.

Hasançebi, B., Terzi, Y., \& Küçük, Z. (2020). Madde güçlük indeksi ve madde ayırt edicilik indeksine dayalı çeldirici analizi. Gümüşhane Üniversitesi Fen Bilimleri Enstitüsü Dergisi, 10(1), 224 240.

Iş1k, N., 2003. Bilim, etik ve eğitim ilişkisi üzerine. Türkiye mühendislik haberleri, 1(423). 124-131.

İdin, Ş., \& Aydoğdu, C. (2016). Kuvvet ve hareket ünitesi başarı testi geçerlik ve güvenirlik araştırması. Eğitim, Bilim ve Teknoloji Araştırmaları Dergisi, 1(1), 14-33. 
Karakaya, F., Arık, S., Çimen, O., \& Yılmaz, M. (2019). Ortaokul öğretmenlerinin Türkiye'deki merkezi sınavlara yönelik görüşlerinin incelenmesi. Amasya Üniversitesi Eğitim Fakültesi Dergisi, 8(2), 352-372.

Karakaya, F., Arık, S., \& Yılmaz, M. (2019). Fen bilgisi ögretmenlerinin kalite, akreditasyon ve uluslararası yeterlilikler çerçevesi standartları hakkındaki görüşlerinin bazı değişkenlere göre incelenmesi. III. Uluslararası Öğretmen Eğitimi ve Akreditasyon Kongresi (ITEAC), (30 Kasım-1 Aralık), Ankara, TR.

Katz, L. J., \& Slomka, G. T. (1999). Achievement Testing. In Goldstein. G. \& Hersen, M. (Eds.). Handbook of Psychological Assessment (pp. 149 - 182). Oxford: Pergamon.

Kenan, O., \& Özmen, H. (2014). Maddenin tanecikli yapısına yönelik iki aşamalı çoktan seçmeli bir testin geliştirilmesi ve uygulanması. Eğitim ve Ögretim Araştırmaları Dergisi, 3(3), 371-378.

Kutlu, E. (2019). FeTeMM destekli fen ögretiminin 8. Sinıf ögrencilerinin sorgulayıcı ögrenme becerileri algısı ve mühendislik bilgi düzeyi üzerindeki etkisi: Basit makineler örneği. Yayımlanmamış yüksek lisans tezi. Van Yüzüncü Yı1 Üniversitesi, Van, TR.

Küçükahmet, L. (Ed.) (2002). Sinıf yönetimi. Ankara: Nobel.

MEB. (2013). 2013 İlköğretim kurumlarl (ilkokullar ve ortaokullar) fen bilimleri dersi (3, 4, 5, 6, 7 ve 8. siniflar) ögretim programı. Ankara: MEB.

MEB. (2017). 2017 Fen bilimleri dersi taslak ögretim programı (ilkokul ve ortaokul 3, 4, 5, 6, 7 ve 8. sinıflar). Ankara: Talim Terbiye Kurulu Başkanlığı (TTKB).

MEB. (2018). 2018 Fen bilimleri dersi ögrretim programı (ilkokul ve ortaokul 3, 4, 5, 6, 7 ve 8. sinıflar). Ankara: TTKB.

MEB. (2020a). 2020 yll stnav uygulama takvimi. 10.05 .2020 tarihinde www.meb.gov.tr/meb_iys_dosyalar/2019_11/20180057_2020_YYIY_SYnav_Uygulama_Tak vimi.pdf adresinden erişilmiştir.

MEB. (2020b). Milli Ĕgitm Bakanlı̆̆ ders kitapları ve eğitim araçları yönetmeliği. 04.10.2020 tarihinde http://mevzuat.meb.gov.tr/dosyalar/1605.pdf adresinden erişilmiştir.

Nakiboğlu, C., \& Güneş Yazar, O. (2019). 9. sınıf “doğa ve kimya” ünitesi ile ilgili başarı testi geliştirilmesi: Geçerlilik ve güvenirlik çalışması. Necatibey Eğitim Fakültesi Elektronik Fen ve Matematik Eğitimi Dergisi (EFMED), 13(1), 76-104.

ÖSYM. (2020). Sinavlar. 10.05.2020 tarihinde https://osym.gov.tr/TR,8793/sinavlar.html adresinden erişilmiştir.

Özcan, H., Boz, C., \& Özkaya, A. (2020). 7. Sınıf Öğrencilerinin Hücre Konusuyla İlgili Anlayışlarını Ölçmeye Yönelik Bir Test Geliştirme Çalışması. Mustafa Kemal Üniversitesi Sosyal Bilimler Enstitüsü Dergisi, 17(46) , 203-233.

Özcan, H., Koca, E., \& Söğüt, M. (2019). Ortaokul öğrencilerinin basınç kavramıyla ilgili anlayışlarını ölçmeye yönelik bir test geliştirme çalışması. Eğitim ve Toplum Araştırmaları Dergisi, 6(1), 130-144.

Özgürlük, B., Ozarkan, H. B., Arıcı, Ö., \& Taş, U. E. (2016). Uluslararası Öğrenci Değerlendirme Programı (PISA) 2015 ulusal raporu. Ankara: MEB Ölçme, Değerlendirme ve Sinav Hizmetleri Genel Müdürlüğü.

Özkan, E., \& Eryılmaz Muştu, Ö., (2018). 8. sınıf basit makineler ünitesine yönelik başarı testi geliştirme: Geçerlik ve güvenirlik çalışması. Hitit Üniversitesi Sosyal Bilimler Enstitüsü Dergisi, 11(1), 737-754.

Özlen, S. (2017). Sekizinci sınıf düzeyinde basit makineler konusunda tasarım temelli STEM etkinliklerinin geliştirilmesi ve etkinliklerin değerlendirilmesi. Yayımlanmamış yüksek lisans tezi. Muğla Sitkı Koçman Üniversitesi, Muğla, TR. 
Sertkaya, Ö. F. (2018). 8. Sinlf fen bilimleri dersi basit makineler ünitesinde algodoo yazılımı ile desteklenen 5E modelinin ögrenci başarı ve tutumuna etkisinin incelenmesi. Yayımlanmamış yüksek lisans tezi. Fırat Üniversitesi, Elazı̆̆, TR.

Shulman, L. S. (1987). Knowledge and teaching: Foundations of the new reform. Harvard Educational Review, 57 (1), 1-23.

Sontay, G., \& Karamustafaoğlu, S. (2017). 5. sınıf fen bilimleri dersi "yer kabuğunun gizemi” ünitesine yönelik başarı testi geliştirme. Fen Bilimleri Öğretim Dergisi, 5(1), 62-86.

Sungur Gül, K., \& Marulcu, İ. (2014). Yöntem olarak mühendislik-dizayna ve ders materyali olarak legolara öğretmen ile öğretmen adaylarının bakış açılarının incelenmesi. Turkish Studies, 9(2), 761-789.

Şen, H. C., \& Eryılmaz, A. (2011). Bir başarı testi geliştirme çalışması: Basit elektrik devreleri başarı testi geçerlik ve güvenirlik araştırması. Yüzüncü Yıl Üniversitesi, Eğitim Fakültesi Dergisi, 8(1), $1-39$.

Şenel Çoruhlu, T., Er Nas, S., \& Keleş, E. (2016). Beyin temelli öğrenme yaklaşımına dayalı web destekli öğretim materyalinin etkililiğinin değerlendirilmesi: Işı ve ses ünitesi. Amasya Üniversitesi Eğitim Fakültesi Dergisi, 5(1), 104-132. doi:10.17539/aej.79756.

Şener, N., \& Taş, E. (2017). Developing achievement test: A research for assessment of 5th grade biology subject. Journal of Education and Learning, 6(2), 254-271.

Telli, A., Yıldırım, H. İ., Şensoy, Ö., \& Yalçın, N. (2004). İlköğretim 7. sınıflarda basit makineler konusunun öğretiminde laboratuvar yönteminin öğrenci başarısına etkisinin araştırılması. Gazi Üniversitesi, Gazi Eğitim Fakültesi Dergisi, 24(3), 291-305.

Tekin, H. (2010). Eğitimde ölçme ve değerlendirme (20. Bask1). Ankara: Yarg1.

Tekindal, S. (Ed.). (2017). Ĕgitimde ölçme ve değerlendirme. Ankara: Pegem Akademi.

Tezbaşaran, A. A. (2008). Likert tipi ölçek hazırlama kılavuzu. Ankara: Türk Psikologlar Derneği.

Tosun, C., \& Taşkesenligil, Y. (2011). Revize edilmiş Bloom'un taksonomisine göre çözeltiler ve fiziksel özellikleri konusunda başarı testinin geliștirilmesi: Geçerlik ve güvenirlik çalıșması. Kastamonu Eğitim Dergisi, 19(2), 499-522.

Tunç, T., \& Kılınç Alpat, S. (2015). Elektrokimyada geçerlik ve güvenirliği sağlanmış kimya başarı testinin geliştirilmesi. Yüksekögretim ve Bilim Dergisi, 5(3), 347-360. doi: 10.5961/jhes.2015.136.

Uğraș, M., \& Genç, Z. (2018). Investigating preschool teacher candidates' STEM teaching intention and the views about STEM education. Bartın University Journal of Faculty of Education, 7(2), 724744.

Voogt, J., \& Roblin, P. N. (2010). 21st century skills. 10.05.2020 tarihinde http://development.todosmedia.com/klassetheater/wp-content/uploads/2015/04/discussie-nota21 st century skills-.pdf adresinden erişilmiştir.

Webb, N., 1997. Determining alignment of expectations and assessments in mathematics and science education. National Institute for Science Education (NISE) Brief, 1(2), 1-11.

Yavaş, S. (2019). Bilim merkezlerindeki sergileri modelleyen atölye çalışmaları ve uygulama sürecinin lise öğrencilerinin kavramsal başarılarına etkisi: Basit makineler örneği. Yayımlanmamış yüksek lisans tezi. Gazi Üniversitesi, Ankara, TR.

Yeşilyurt, E. (2012). Fen ve teknoloji dersinde kullanılan ölçme -değerlendirme yöntemleri ve karşılaşılan güçlükler. Turkish Studies, 7(2), 1183-1205.

Yıldırım, A., \& Şimşek, H. (2018). Sosyal bilimlerde nitel araştırma yöntemleri (11. Baskı). Ankara: Seçkin. 
Yumuşak, A., \& Aycan, Ş. (2002). Fen bilgisi eğitiminde bilgisayar destekli çalışmanın faydaları: Demirci (Manisa)'de bir örnek. M. ̈̈. Atatürk Eğitim Fakültesi Eğitim Bilimleri Dergisi, (16), 197-204.

Zimmerman, B. J. (1989). A social cognitive view of self-regulated academic learning. Journal of Educational Psychology, 81 (3), 329-339.

\section{Extended Abstract}

\section{Purpose and Significance}

In this study, it was aimed to develop a test to measure the academic achievements of eighth-grade students towards the achievements of the basic machines unit in a science course. Successful education is possible with education programs that include the relationship between purpose, content, learningteaching process, and assessment. Assessment, which takes place at the last step of the curriculum, is one of the most important processes related to other dimensions. The assessment process is very important in determining the functionality of the curriculum, the efficiency of teaching strategies, methods and techniques, and the difficulties and success situations of learners in the learning process (Baykul, 2015; Demirel, 2005; Grounlund, 1985; Küçükahmet, 2002). Achievement tests are data collection tools used to measure the academic performance of students on any subject. Achievement tests are important in terms of detecting meaningful learning in addition to observing, analyzing, and evaluating changes in learning. For this reason, valid and reliable success tests are needed that provide precise measurement of expected results in the relevant discipline. It is thought that the academic achievement test developed in this study will contribute to the literature in measuring and evaluating the academic achievement regarding the Simple Machines Unit.

\section{Methods and Procedure}

In this study, a valid and reliable test development study consisting of multiple-choice questions was conducted to measure the conceptual understanding of eighth-grade students' achievements of the basic machine's unit of the science course. The study group of the study consisted of 160 eighth-grade students on the "simple machines" unit, who were studying in a state secondary school in the central district of Aksaray/Turkey.

A seven-step method was followed in the development of the Simple Machines Unit Academic Achievement Test (SMUAAT). These stages are: Determination of the purpose of the test (purpose of using the test by students), determination of the features to be measured in the test (examination of the literature on the subject, table of indicators), writing of items (determination of the question type to be used, points of consideration in item writing), item editing (expert opinion), preparation of trial form (selection of trial group, preparation of trial form, implementation), pilot test application (application of trial form, expert opinion) and estimation of statistics of final test item scoring, analysis and selection (estimation of test statistics, scoring, item analysis, and item selection) (Baykul, 2015; Crocker \& Algina, 1986). Classical Test Theory was used in item scoring of the test (Baykul, 2015). The reliability of the test was determined by calculating the KR-21 internal consistency coefficient.

\section{Results}

After the pilot test, SMUAAT, consisting of 20 multiple-choice questions, was applied to 160 eighthgrade students to estimate the statistics of the test. As a result of the item difficulty and item discrimination analysis, two items with an item discrimination index of 0.19 or less were excluded from the scope of the test, and the final statistics of the test were carried out with the SMUAAT consisting of 18 multiple-choice questions. As a result of the item analysis, it was found that the discrimination index of 12 items of the test was 0.40 and above (very good) and three items were between 0.31 and 0.40 (good); The discrimination index of the remaining three items was determined to be between 0.21 and 0.30 (low, should be reviewed). When the item difficulty index of the test is examined, it is seen that 13 out of 18 items have an item difficulty index of 0.50 and above; five of them were determined to have item difficulty index below 0.50 . Following the analysis made to estimate the statistics of the final test, the following data were obtained for the general SMUAAT: Arithmetic mean $=10,798$; standard 
deviation $=3.795$; variance $=14,409$; item difficulty index $(\mathrm{p})=0.57$ "average difficulty"; item discrimination index $(\mathrm{rjx})=0.50$ "very good". As a result of the analysis made for the reliability of the test, it was determined that the KR21 value was 0.741 and the test was reliable enough $(\mathrm{KR}-21 \geq 0.70)$ (Büyüköztürk, 2013).

\section{Discussion and Conclusions}

As a result of this research, a valid and reliable achievement test consisting of 18 multiple-choice items was developed. It is thought that SMUAAT, which is obtained as a result of the research, will contribute to the literature for measurement and evaluation during the development of curricula. It is thought that the success test development stages used in this research will guide researchers in developing valid and reliable success tests in different subject areas and disciplines.

* Yazarlar makaleye eşit oranda katkı sağlamış olduklarını beyan ederler. 